\title{
RÉGIÓK FELEMELKEDÉSE ÉS HANYATLÁSA REGIONÁLIS ÁTALAKULÁS A BRIT-SZIGETEKEN
}

(Szerkesztette: Horváth Gyula, MTA RKK Pécs, 1997. p. 440)

\section{MÉSZÁROS NÓRA}

1993-ban "Régiók Európája" címmel indult el egy új sorozat a MTA Regionális Kutatások Központja gondozásában, melynek alapvető célja, hogy bemutassa az egyes európai országok területi fejlődését, regionális politikájának sajátos vonásait. Az első kőtet az olasz gazdaság térbeli folyamataival kapcsolatos tanulmányok gyưjjteménye, melyeken keresztül képet kapunk a modernizációról és annak terủleti hatásairól. 1997-ben jelent meg "Regionális átalakulás a Brit-szigeteken" címmel a sorozat második kötete, mely nemcsak az Egyesült Királyság, hanem az ir Köztársaság terủleti fejlődésének történeti folyamatait is bemutatja, magában foglalva e folyamat legfontosabb mozgatórugóit, a kialakult helyzet korlátait és további lehetőségeit, a közigazgatási rendszer múködésének jellemzőit, valamint a regionális politika eszköz- és intézményrendszerét.

A téma aktualitásához nem fér kétség, hiszen Magyarország az Európai Unióhoz való csatlakozásra készull és a felzárkózás folyamatában fontos szempont az európai normákhoz való alkalmazkodás. Ezért nagyon hasznos lehet, az EU-hoz tartozó országok tapasztalatait figyelembe venni. Erre kiváló példa Írország, melynek fejlettsége, gazdasági szerkezete Magyarországhoz sok tekintetben hasonló volt. Az Európai Unióhoz történö csatlakozása és a nyitott piacgazdaság térhódítása ezen ország esetében is olyan folyamatokat indított el, mely politikai, társadalmi és gazdasági értelemben is jelentős változásokat eredményezett. A változásokra adott reakciók, ezek eredményeinek, elönyeinek és hátrányainak ismerete, a kedvezó és kedvezötlen tapasztalatok felismerése és szelektálása, adaptálása a magyarországi viszonyokhoz sok segítséget nyủjthat a magyar regionális politika alakításában.

A másik ország, melyről a kötet szól, az Egyesült Királyság, a területi politika kialakulásának klasszikus hazája, hiszen a korai iparosodás hátrảnyos vonásai, a nỏvekvő területi kullönbségek itt tették szükségessé elsőként a „külső” (kormányzati) beavatkozást. Az ipari depressziós válságövezetek problémájának megoldására született meg 1934-ben egy olyan törvény, mely a világon elsőként tartalmazta a kormányzati beavatkozás lehetőségét piacgazdasági viszonyok között. Anglia nemcsak ekkor, hanem a későbbi gazdasági változásokra is az elsők között reagált, melynek folyamatát és eredményeit részletesen mutatja be a kötet.

A kőnyv négy nagyobb egységre tagolódik. A területi fejlődéstörténeti folyamatait, a regionális fejlödési pályák elkülönủlését, a regionális politikák egyedi jogi-, eszkőz- és intézményrendszerét, valamint az új kihívásokat bemutató bevezető tanulmányt három nagy témakör követi.

Az első rész az 1970-es évektől napjainkig tárja fel a Brit-szigetek változó makroökonómiai folyamatait és a regionális politikája közötti összefüggéseket. Megtudhatjuk, hogy az Egyesullt Királyság egyes kormányai milyen intézkedéseket hoztak az ipari térségek fejlesztésére, s hogyan ütközött a piaci racionalitás a 
kormányzati célokkal. A már kialakult különbségek mérséklése nehéz feladatának bizonyult, hiszen a periféria eleve egyenlötlen versenyre kényszerül a centrummal szemben minden területen, $s$ erre az ördögi körre megoldást csak egy olyan állami beavatkozás jelenthet, mely nem helyettesiti a piaci alkalmazkodást, hanem elósegíti az ipar stratégiai adaptációját a megváltozott világpiaci trendekhez. A szerzö ezt a folyamatot egy konkrét példán keresztül, Glasgow átalakulásán, a regionális tanács szerepének, tevékenységének leírásán keresztül érzékelteti.

Írországban egészen más jellegú problémák merültek fel az elmúlt évtizedekben. Egyrészt földrajzi, másrészt gazdasági és politikai okok játszottak közre abban, hogy az országban nem csak az északi és a déli, hanem a nyugati és a keleti területek között is igen jelentös különbségeket tapasztalhatunk úgy nemzeti, mint regionális illetve falu-város viszonylatban is. Az ír gazdaság nem csak a brit gazdaságtól, hanem a külföldi vállalatoktól is eröteljes függésbe került. Bár a külföldi töke befektetések ösztönzését a kormányzat azért vállalta fel, hogy a vállalatközi együttmüködés révén lökést adjon a hazai cégek fejlödésének. Kérdéses, hogy ezek a sikerek valódiak vagy csak látszat-sikerként értékelhetőek-e. $\mathrm{Az}$ országban egyelöre még nem sikerült egy olyan hosszú távú gazdaságpolitikát kidolgozni, mely megfelelne az ország alapvetó igényeinek, s stabil környezetet biztosítana a gazdaság növekedésének fenntartásához. Az egyes gazdaságfejlesztési stratégiák sikertelenségét egyes szakemberek a vállalkozói vitalitás, a belső információs hálózatok és a külső kapcsolatok hiányának tulajdonítják, míg mások az ipar ruralizálását tekintik a kudarcok okának.

A kötet második részében a posztindusztriális korszak fejlödésének mozgatórugóit ismerhetjük meg. Elemzésre kerül a tercier szektor, az innováció, a csúcstechnológia, a külföldi tóke, a turizmus és a határmenti együttmüködések regionális fejlödésben betöltött szerepe. Két angol régió (Yorkshire-Humberside és Dél-Wales) gazdasági helyzetének, fejlesztési stratégiájának leírása és értékelése mellett megismerkedhetünk egy nagyon sajátos és egyedülálló regionális együttmúködés történetével is. Az utóbbi tanulmány bemutatja, hogyan reagált a Csalagút megépítésére vonatkozó döntésre egymástól teljesen eltérő gazdaságiközigazgatási szerepkörrel rendelkezö régió két különböző országban, s elemzi, hogyan lehet intenzív, kölcsönös tanulási folyamat révén egy sikeres határ menti együttmüködést létrehozni és fenntartani.

A harmadik rész tanulmányai révén megismerjük a regionális politika eszközrendszerét, és a regionális szervezödéseket, részletesen tárgyalva a hatalmi megosztottság fokát, valamint a központi kormányzat és a helyi önkormányzatok törekvéseit, ezek ellentmondásait és a megoldási lehetőségeket. Az első tanulmány szerzője elemzi az 1969-ben elindított "Urban programme" eredményeit, annak hozzájárulását a helyi gazdaságfejlesztésben való érdekeltség megteremtéséhez ill. növeléséhez, hogy milyen távlatokat nyithat meg a kulturális ipar, mint ơnállo létjogosultsággal rendelkező produktív ágazat, és milyen szerepet tölt be a területi irányításban a Skót ill. a Walesi Hivatal. A 3. fejezet felhívja a figyelmet arra is, hogy İrországban milyen problémákat jelent, hogy a helyi önkormányzatok a szolgáltatásszervezés helyett a központi kormányzat ügynökségeként állami feladatokat látnak el és a Gaeltacht területek (városi jogállású település nélküli rurális régiók) fejlesztési koncepcióján keresztül bepillantást nyerhetünk a helyi 
gazdaságfejlesztés alulról felfelé építkező ("bottom-up") stratégiájának törekvéseibe és tapasztalataiba is.

A kötet által nyújtott átfogó képböl hiányzik néhány érdekes elem, mint pl. az Egyesült Királyságban méretüknél fogva is oly jelentös szerepet betöltö nemzeti parkok és az ott folyó gazdálkodás, a rurális térségek helyzetének részletesebb elemzése és az angliai turizmus szerepének bemutatása. Talán több szót érdemelt volna az Európai Unió támogatásainak szerepe, illetve a regionális marketing egyre növekvö jelentősége. Mindezek ellenére a kötet összességében alapos, részletes, mindenre kiterjedö áttekintést nyújt a Brit-szigetek regionális fejlödését érintő kérdésekről, s a pillanatnyi állapot elemzésén túl, bemutatja az idevezető utat és feltárja a továbblépés lehetőségeit is. 